\title{
Organic fertilization affecting pests and production of Lippia sidoides Cham. (Verbenacea)
}

\author{
LEITE, G.L.D.*; SOUZA, M.F.; SOUZA JUNIOR, I.T.; FIGUEIREDO, L.S.; BONFIM, F.P.G.; MARTINS, E.R. \\ UFMG, Insetário G.W.G. de Moraes, Instituto de Ciências Agrárias, Av. Universitária, n. 1000, B. Universitário, \\ Cx. Postal 135, CEP: 39404-006, Montes Claros - Brasil._～$\quad{ }^{*}$ gldleite@ig.com.br
}

\begin{abstract}
The objective of this paper was to study the effect of four levels of organic fertilization $(0,3,6$ and $9 \mathrm{~kg} \mathrm{~m}-2)$ to produce the essential oil of Lippia sidoides Cham. (Verbenacea) and its pests. A higher number of red mite Tetranychus sp. (Acari: Tetranychiidae) was observed on the abaxial face of the median and basal leaves of $L$. sidoides plants with eight weeks of age cultivated with $6 \mathrm{~kg} \mathrm{~m}-2$ of organic fertilization. On the other hand, the smallest number of this mite was noted in control $(0 \mathrm{~kg} \mathrm{~m}-2)$. L. sidoides cultivated with $6 \mathrm{~kg} \mathrm{~m}-2$ of organic fertilization produced a greater quantity of essential oil. The highest number of mealy bug Phenacoccus sp. (Hemiptera: Pseudococcidae) was observed on the apical leaves (both leaf surfaces) of $L$. sidoides plants with nine and ten weeks of age cultivated with $3 \mathrm{~kg} \mathrm{~m}-2$ of organic fertilization. No significant effect of the organic fertilization on Aphis gossypii Glover (Hemiptera: Aphididae) was detected. However, a greater number of this aphid and of its predator Scymnus sp. (Coleoptera: Coccinelidae) was observed on the abaxial face of the bottom leaves of $L$. sidoides plants with eight weeks of age. The dose of organic fertilization recommended for the production of essential oil of $\mathrm{L}$. Sidoides is $6 \mathrm{~kg} \mathrm{~m}-2$, however, one must pay attention to the fact this dosage favors the attack by Tetranychus sp.. And, when needed, pulverization must always be directed to the lower surface of the leaf.
\end{abstract}

Keywords: medicinal plants, insects, mites, family farm, competition

RESUMO: Adubação orgânica afetando a ocorrência de pragas e a produção de Óleo essencial em Lippia sidoides Cham. (Verbenacea). O objetivo deste trabalho foi avaliar o efeito de quatro níveis de adubação orgânica $(0,3,6$, e 9 kg m-2) na produção de óleo essencial de Lippia sidoides Cham. (Verbenacea) e de suas pragas. Observou-se maior número de ácaro vermelho Tetranychus sp. (Acari: Tetranychiidae) na face inferior das folhas dos terços medianos e basais das plantas de L. sidoides com oito semanas de idade cultivadas com $6 \mathrm{~kg} \mathrm{~m}-2$ de adubo orgânico. Por outro lado, a menor quantidade deste ácaro foi notada na testemunha $(0 \mathrm{~kg} \mathrm{~m}-2)$. L. sidoides cultivada com $6 \mathrm{~kg} \mathrm{~m}-2$ de adubo orgânico produziu maior quantidade de óleo essencial. Observou-se maior número de cochonilhas Phenacoccus sp. (Hemiptera: Pseudococcidae) nas folhas apicais, sem distinção de face foliar, das plantas de L. sidoides com nove e 10 semanas de idade cultivadas com $3 \mathrm{~kg} \mathrm{~m}-2$ de adubo orgânico. Não se detectou efeito significativo de adubo orgânico sobre Aphis gossypii Glover (Hemiptera: Aphididae). Contudo, observou-se maior número desse pulgão bem como de seu predador Scymnus sp. (Coleoptera: Coccinelidae) nas faces abaxiais das folhas basais das plantas de L. sidoides com oito semanas de idade. A dose de adubo orgânico recomendada para produção de óleo essencial de L. sidoides é de $6 \mathrm{~kg} \mathrm{~m}$-2. Contudo, essa dosagem favorece o ataque de Tetranychus sp. e, quando necessário, deve-se dirigir a pulverização sempre para a face inferior da folha, local preferencial de ataque dos artrópodes.

Palavras-chave: plantas medicinais, insetos, ácaros, agricultura familiar, competição

\section{INTRODUCTION}

Lippia sidoides Cham. (Verbenacea) is originally from Brazil, and its propagation is obtained by cutting or air layering. Its main chemical constituents are essential oils, containing more than
$60 \%$ of thymol or a mixture of thymol and cavacrol, with antimicrobial action against throat infections, dental caries, impingens, acne, ulcers, scabies, dandruff, bad smells of feet and armpits, mange

Recebido para publicação em 29/09/2010

Aceito para publicação em 20/02/2013

Rev. Bras. PI. Med., Campinas, v.15, n.4, p.551-556, 2013. 
infections and athlete's foot, and antispasmodic (Martins et al., 1994; Lorenzi \& Matos, 2002). The compounds tectol and lipsidoquinone exhibit significant activity against human leukemic cells (Costa et al., 2001; Carvalho et al., 2003; Girão et al., 2003). In dogs, the essential oil of this plant reduces marginal gingivitis caused by bacteria, and shows larvicidal activity against Aedes aegypti L. (Diptera: Culicidae) (Carvalho et al., 2003; Girão et al., 2003). Medicinal plants are an interesting and profitable alternative for Brazilian agriculture (Simões et al., 2000). Therefore, it is necessary to study the nutritional requirements of the plant to commercial crops (Silva et al., 2009). For the cultivation of medicinal plants, such as $L$. sidoides, is recommended the use of organic fertilization to improve the physical and biological properties of soil, correcting possible deficiencies of macro and micronutrients in soil and can reduce the attack of insect herbivores (Primavesi, 1988; Martins et al., 1994; Sartório et al., 2000; Leite et al., 2006). However, the excess of organic fertilization can also promote the attack of insects in medicinal plants (Leite et al., 2005). Silva et al. (2009) verified that the omission of nutrients affected the attack of insects in L. sidoides.

The species of medicinal plants usually show resistance to attack by diseases and pests (Leite et al., 2006). But for some non-balance, there may be attacks of pests and diseases harmful levels to these species of plants (Leite et al., 2005; Silva et al., 2009). Thus, nutrition (food factor) is very important in the distribution (spatial and temporal) and abundance of insects, directly or indirectly influencing the population of insects in biological, morphological and behavioral processes (Dent, 1995; Gallo et al., 2002).

Thus, the objective of this paper was to study the effect of organic fertilization to produce the essential oil of $L$. Sidoides and its pests and the spatial and temporal distribution of these pests.

\section{MATERIAL AND METHOD}

Lippia sidoides exsiccates (dried specimens) is in the Federal University of Juiz de Fora. The experiment was carried out at in the "Instituto de Ciências Agrárias da Universidade Federal de Minas Gerais" from June to November 2006, in greenhouse conditions. The soil used was a dystrophic red yellow latosol alico, collected in the layer of $0-20 \mathrm{~cm}$ of depth (Embrapa, 1999) in savanna vegetation placed in the municipality of Montes Claros, Minas Gerais State, Brazil, with the following attributes, as determined Embrapa (1997): $\mathrm{pH}$ in water 4.1, phosphorus $1 \mathrm{mg}$ $\mathrm{dm}^{-3}$, calcium 2 mmolc $\mathrm{dm}^{-3}$, magnesium $1 \mathrm{mmolc}$ $\mathrm{dm}^{-3}$, potassium $0.5 \mathrm{mmolc} \mathrm{dm}^{-3}$, aluminum 20 mmolc dm ${ }^{-3}, \mathrm{H}+\mathrm{Al} 100 \mathrm{mmolc} \mathrm{dm}^{-3}$, zinc $0.3 \mathrm{mg} \mathrm{dm}^{-3}$, manganese $2 \mathrm{mg} \mathrm{dm}^{-3}$, iron $6 \mathrm{mg} \mathrm{dm}^{-3}$, cuprum 0.1 $\mathrm{mg} \mathrm{dm}^{-3}$, boron $0.1 \mathrm{mg} \mathrm{dm}^{-3}$, organic matter $20 \mathrm{~g} \mathrm{~kg}^{-}$ 1 , sand $500 \mathrm{~g} \mathrm{~kg}^{-1}$, silt $80 \mathrm{~g} \mathrm{~kg}^{-1}$ and clay $420 \mathrm{~g} \mathrm{~kg}^{-1}$.

The experimental design was completely casual with seven repetitions, with each repetition consisted of two plants/pot. The seedlings were produced by cutting in commercial substrate (vermiculite) in rooting bed under controlled humidity. After rooting, about 45 days, the seedlings were transferred to pots with $3 \mathrm{dm}^{3}$ of soil, with assessments beginning next month. The treatments were the following levels of organic fertilization: 0 , 3,6 and $9 \mathrm{~kg} / \mathrm{m}^{2}$ of manure from cow tanned. The irrigation was made with distilled water in order to avoid the contamination and to commit the influence of the fertilization.

Weekly, in the morning part, we evaluated (visual inspection) the numbers of arthropods, in both the leaf faces, on the bottom, middle and apical parts of each plant (three leaves per plant) in two plants/pot (Silva et al., 2009) as well as their damages. Insects were collected, using an aspirator or tweezers, and held individually, in $8 \times 2 \mathrm{~cm}$ glass flasks containing $70 \%$ ethanol, for identification.

The plants were harvested after 90 days of the cuttings were planted. Then samples of fresh material were used to determine the level of essential oil, by hydrodistillation, using Clevenger equipment (Figueiredo et al., 2009; Melo et al., 2011). The aerial part was fragmented, weighed, the sample of approximately $100 \mathrm{~g}$ of the plant, placed in a glass flask with distilled water (Figueiredo et al., 2009; Melo et al., 2011). The extraction process was conducted for four hours. After this period of time, the product resulting from the extraction was submitted to a drying process in a forced air circulation chamber for the determination of the dry matter sample $\left(60^{\circ} \mathrm{C}\right.$, to constant weight) (Figueiredo et al., 2009; Melo et al., 2011). The content of essential oil was estimated based on the dry material ( $\mathrm{g}$ of oil $100 \mathrm{~g}^{-1}$ of dry material) (Figueiredo et al., 2009; Melo et al., 2011).

The collected data were submitted to statistical analysis and to the tests Tukey to $5 \%$ of probability.

\section{RESULT AND DISCUSSION}

The higher number of red mite Tetranychus sp. (Acari: Tetranychiidae) was observed on the abaxial face of the median and basal leaves of $L$. sidoides plants with eight weeks of age cultivated with $6 \mathrm{~kg} \mathrm{~m}^{-2}$ of organic fertilization (Figures 1-4), resulting in numerous chlorotic spots in the leaves, and consequently, reducing their capacity to realize photosynthetic, as observe by Silva et al. (2009). On the other hand, the smaller number of this mite 
was noted in control $\left(0 \mathrm{~kg} \mathrm{~m}^{-2}\right)$ (Figure 1). Silva et al. (2009) observed higher attack and damage of red mite Tetranychus sp. in $L$. sidoides seedlings whose soil had not received fertilization of phosphorus (low phosphorus), but had received supplies of nitrogen. Plants with phosphorus deficiency can block protein synthesis resulting in accumulation of free aminoacids (Marschner, 1995), providing better nutrition for arthropods (Chaboussou, 1999; Gallo et al., 2002). Another possible explanation for the largest attack of Tetranychus sp in L. sidoides plants cultivated with $6 \mathrm{~kg} \mathrm{~m}^{-2}$ of organic fertilization is that this same fertilizing was observed the largest producer of essential oils (Figure 5), perhaps these are factors of susceptibility to this mite, increasing its attack. Leite et al. (2005) studying the same range of doses of organic fertilization that this work, also observed increased for quantity production (number of capitulum plant ${ }^{-1}$ ) and quality (tenor of total flavonoids) of Calendula officinalis L. with $6 \mathrm{~kg}$ $\mathrm{m}^{-2}$ as well as the greater attack of aphids Uroleucon ambrosiae f. lizerianum (Hemiptera: Aphididae) on plants fertilized with 6 and $9 \mathrm{~kg} \mathrm{~m}^{-2}$ organic fertilization. Silva et al. (2009) also noted that the red mite preferred to attack the same parts of the $L$.
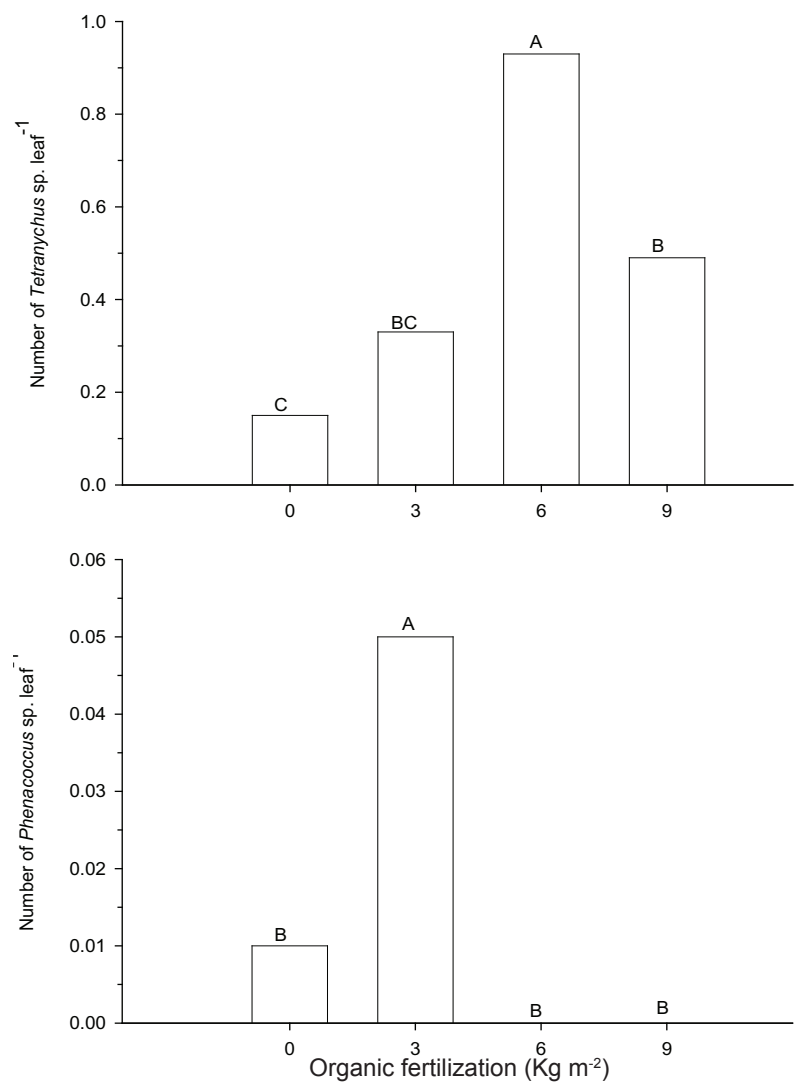

FIGURE 1. Effect of organic fertilization in the number of Tetranychus sp. and Phenacoccus sp. leaf ${ }^{1}$ of Lippia sidoides. Means with different letter differ at $p<0.05$ (Tukey). sidoides plants with 90 days of age.

The higher number of mealy bug Phenacoccus sp. (Hemiptera: Pseudococcidae) was observed on the apical leaves (both leaf surfaces) of $L$. sidoides plants with nine and ten weeks of age cultivated with $3 \mathrm{~kg} \mathrm{~m}^{-2}$ of organic fertilization (Figures 1,2 e 4), resulting in the formation of sooty mold on leaves, coming fungal attack on the substrate formed by the sugary liquid removed by this insect, as a result of suction sap of plants, as observed by Silva et al. (2009). Silva et al. (2009) reported greater attack of Phenacoccus sp. in L. sidoides seedlings whose soil did not received calcium (low tenor) but had been fertilized with $\mathrm{N}$. The Ca participant's cell wall synthesis and lignin (Taiz \& Zeiger, 2004), and induction of plant resistance to attack by sucking insects (Correa et al., 2005; Gomes et al., 2005). On the other words, the plants, probably, had more free aminoacid and cell wall more weak, favoring the attack of Phenacoccus sp. Silva et al. (2009) also observed that Phenacoccus sp. preferred to attack the abaxial face of apical part of $L$. sidoides plants at the end of the experiment (120 days). A possible explanation for the largest attack of Phenacoccus sp. in plants fertilized with $3 \mathrm{~kg} \mathrm{~m}^{-2}$ of organic fertilization is the possibility of an antibiotic or non-preference effects of $L$. sidoides essential oils on this insect in higher doses of organic fertilization (Figure 5). Medicinal plants, in general, are less attacked by insects because of their chemical compounds (Leite et al., 2006).

No significant effect was detected between organic fertilization and Aphis gossypii Glover (Hemiptera: Aphididae). However, the greater number of this aphids and its predator Scymnus sp. (Coleoptera: Coccinelidae) was noted on the abaxial face of the bottom leaves of $L$. sidoides plants with eight weeks of age. (Figuras 2-4), similar fact also observed by Silva et al. (2009) in seedlings of this plant.

Interesting to note the spatial and temporal distribution of Tetranychus sp., Phenacoccus sp. and Aphis gossypii on plants of $L$. sidoides, because of this work as well as Silva et al. (2009), these pests maintained a certain standard among them. In general, what is observed are colonization niches, because Tetranychus sp. has occupied the median or basal part of plants, alternating with A. gossypii, since that both the pests attacked plants almost the same time, and Phenacoccus sp. colonized the apical part of plants and more the end of $L$. sidoides cultivation (Figures 2 and 4) (Silva et al., 2009). Thus, maybe these pests avoid a direct competition between them, as observed for aphids (Vehrs et al., 1992).

Another factor that may be affecting the temporal distribution these arthropods is the 

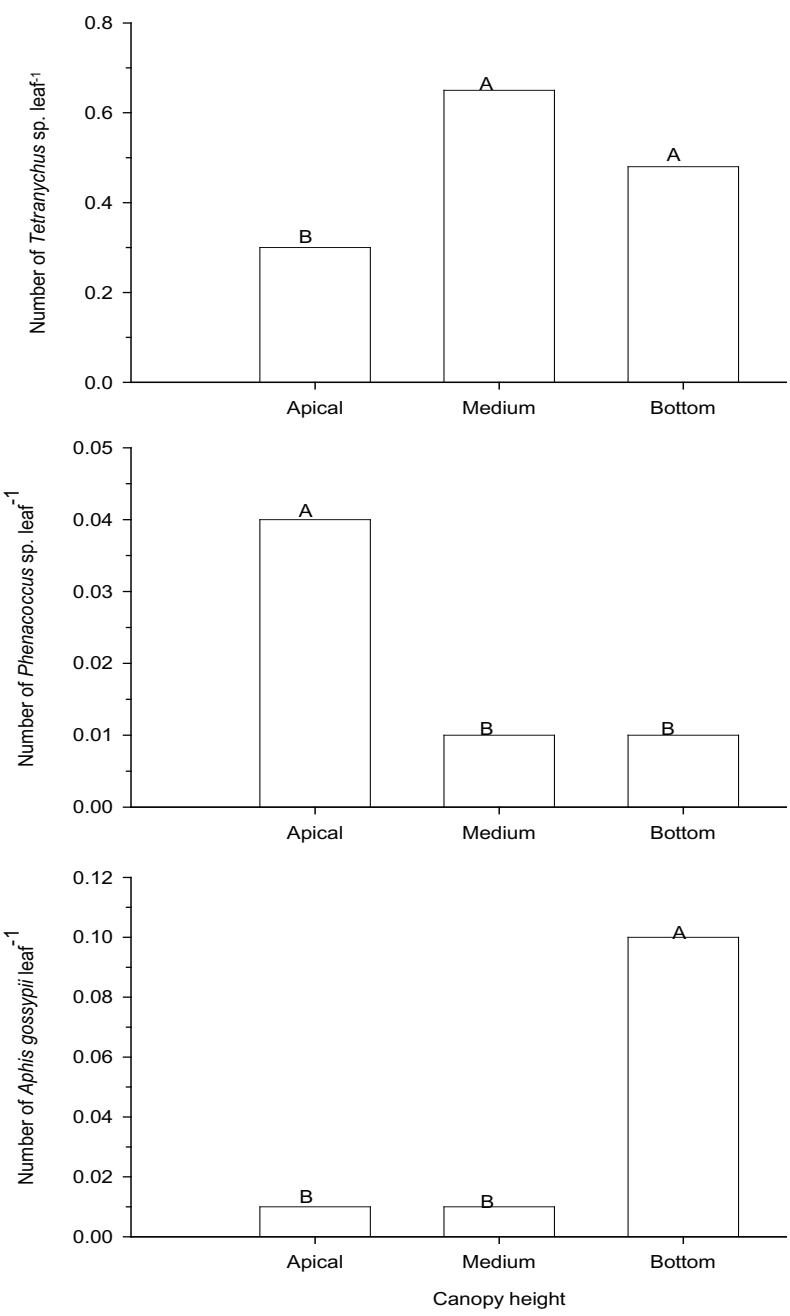

FIGURE 2. Effect of canopy height in the number of Tetranychus sp., Phenacoccus sp. and Aphis gossypii leaf ${ }^{-1}$ of Lippia sidoides. Means with different letter differ at $p<0.05$ (Tukey).

variation of essential oils concentration with the aging plant. Figueiredo et al. (2009) collected the $L$. sidoides at $120,180,240,300$ and 360 days after transplanting and observed increased production of essential oils to 180 days. In this study, seedlings of this plant was studied, but we can suggest, noting the results of Figueiredo et al. (2009), that the highest concentration of essential oil occurred in seedlings with 10 weeks of age, which explains the largest attack of Phenacoccus sp. and smallest of Tetranychus sp. and A. gossypii. In other words, Phenacoccus sp. is less affected negatively or positively affected by essential oils of $L$. sidoides, the opposite occurred with the two other arthropods. Thinking in this line of reasoning, in general, the apical leaves has greater density of glandular trichomes as well as higher quantity of intact trichomes (less broken) than the basal leaves (Leite et al., 1999), which may explain why $A$.
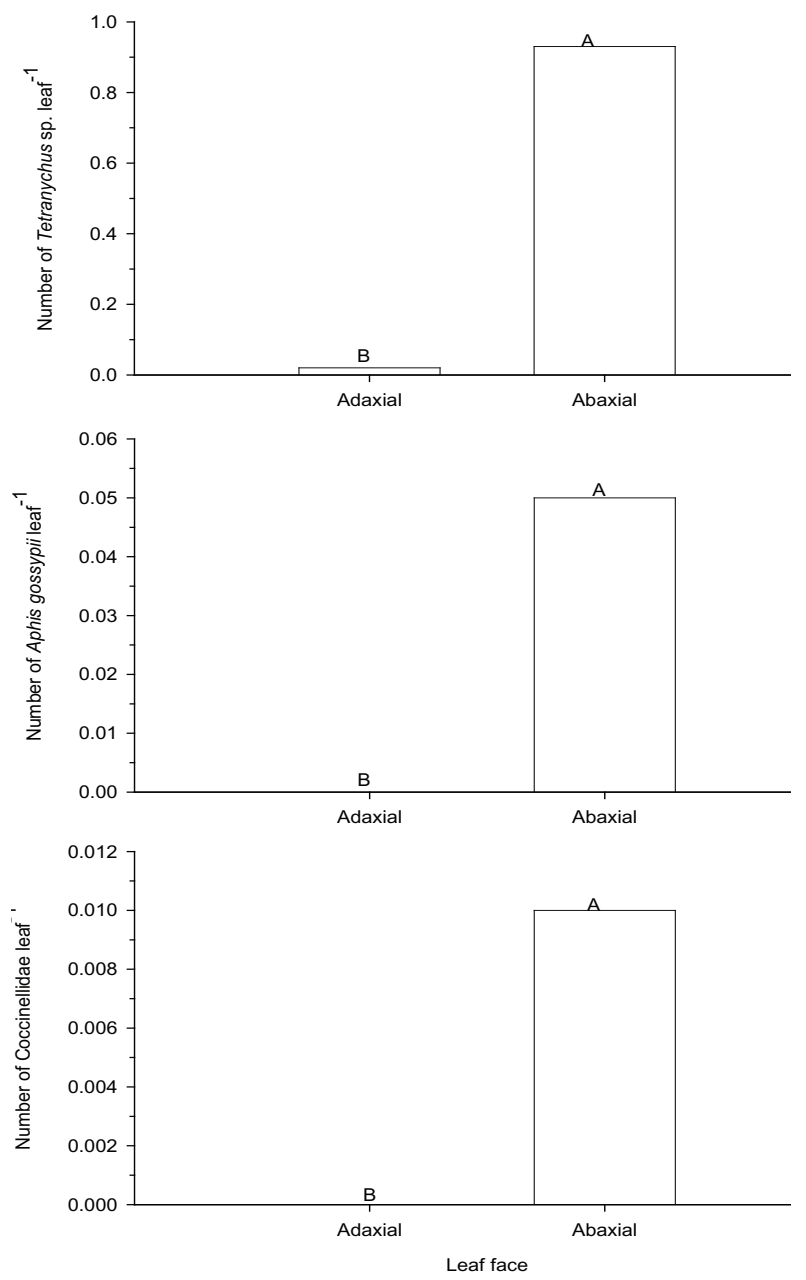

FIGURE 3. Effect of leaf face in the number of Tetranychus sp., Aphis gossypii and Coccinellidae leaf $^{-1}$ of Lippia sidoides. Means with different letter differ at $p<0.05$ (Tukey).

gossypii and Tetranychus sp. preferentially attacked the middle and basal leaves of $L$. sidoides seedlings, the opposite occurred with the Phenacoccus sp..

Therefore, it is necessary to know qualitatively and quantitatively the chemical constituents of a plant during its growth (Leite et al., 2001; Figueiredo et al., 2009) as well as over its canopy (Leite et al., 1999). Because these factors may be affecting the colonization of $L$. sidoides by herbivores as it has low capacity to host arthropods (Leite et al., 2006), probably due to deleterious effects on these pests (Carvalho et al., 2003; Santiago et al., 2008).

We observed that increasing the dose of organic fertilization increased fresh and dry weight and essential oil $(\mathrm{mL})$, but the higher production of essential oil per dry weight was observed around 6 $\mathrm{kg} \mathrm{m}^{-2}$ (Figure 5). Souza et al. (2010) noted higher production of essential oil production (fresh or dry 

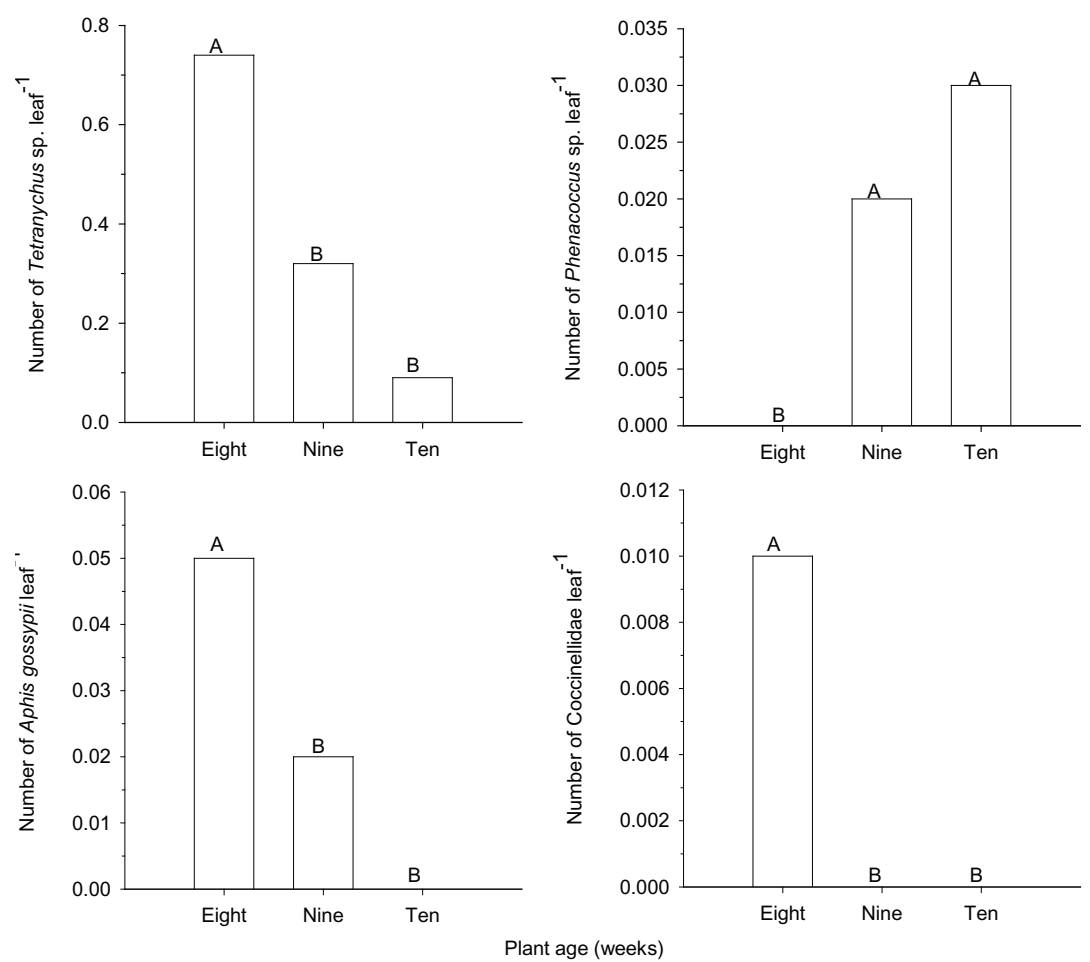

FIGURE 4. Effect of plant age in the number of Tetranychus sp., Phenacoccus sp., Aphis gossypii and Coccinellidae leaf ${ }^{-1}$ of Lippia sidoides. Means with different letter differ at $p<0.05$ (Tukey).
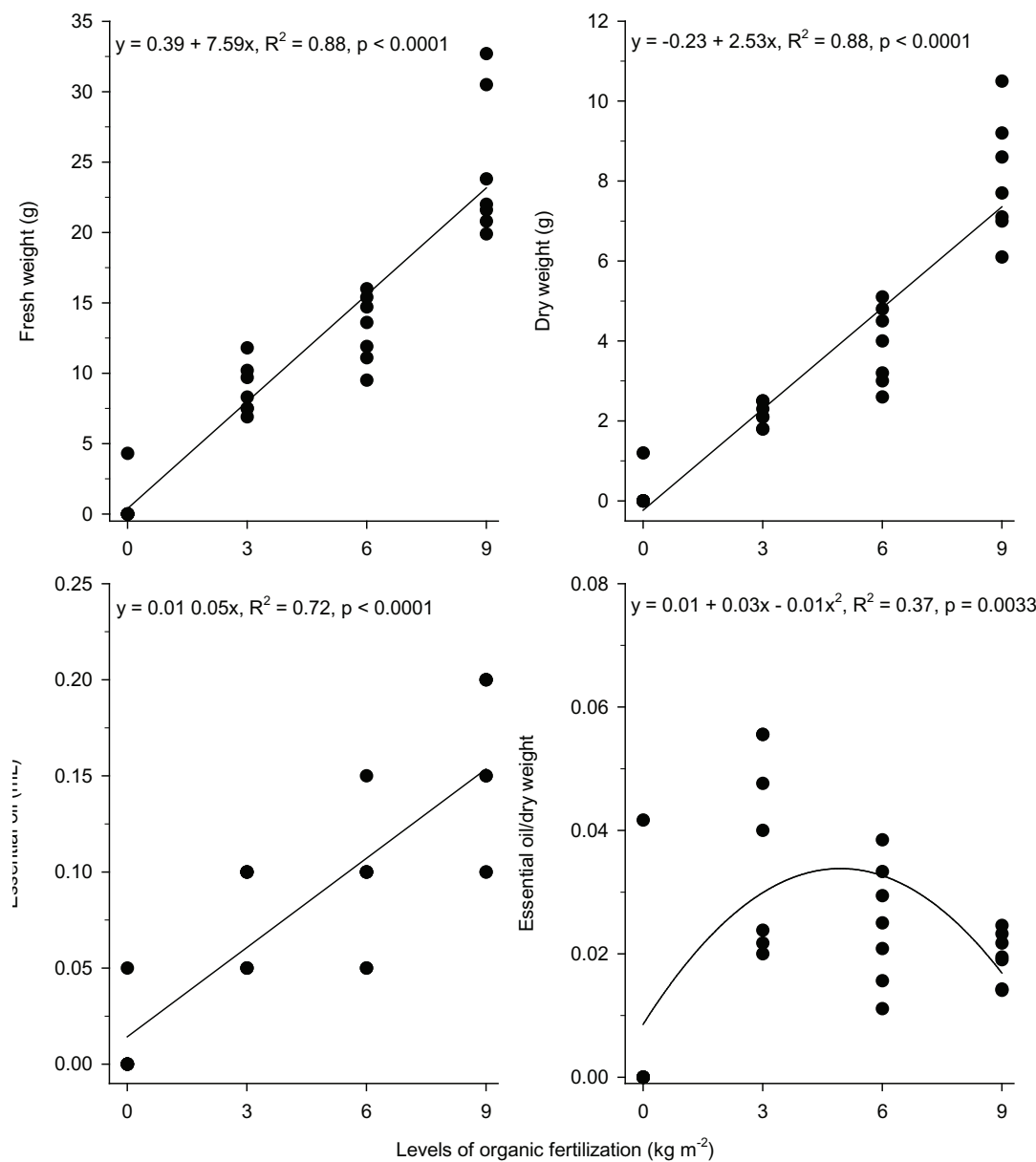

FIGURE 5. Effect of four levels of organic fertilization $\left(0,3,6\right.$ and $\left.9 \mathrm{~kg} \mathrm{~m}^{-2}\right)$ on production of fresch and dry weight (g), essential oil, and essential oil/dry weight by Lippia sidoides Cham. 
matter) in Lippia citriodora Kunth under treatments with bovine manure (32 $\left.\mathrm{t} \mathrm{ha}^{-1}\right)$. Lippia sidoides produce great quantity of essential oil content at 180 days after transplanting (Figueiredo et al., 2009).

In summary, the dose of organic fertilization recommended for production of essential oil of $L$. Sidoides is $6 \mathrm{~kg} \mathrm{~m}^{-2}$, however one must be attentive the attack of Tetranychus sp., as this dosage favors them.

\section{ACKNOWLEDGMENT}

To Dr. Victor Pirovani and Prof. Paulo Sérgio Fiuza Ferreira (Universidade Federal de Viçosa) and Prof. Ana Lúcia Benfatti Gonzalez Peronti (Universidade Federal de São Carlos) for identification of meal bugs and to Banco do Nordeste for finantial support.

\section{REFERENCE}

CARVALHO, A.F.U. et al.. Larvicidal activity of the essential oil from Lippia sidoides Cham. against Aedes aegypti Linn. Memórias do Instituto Oswaldo Cruz, v.98, n.4, p.569-71, 2003.

CORREA, R.S.B. et al. Silicon and acibenzolar-S-methyl as resistance inducers in cucumber, against the whitefly Bemisia tabaci (Gennadius) (Hemiptera: Aleyrodidae) biotype B. Neotropical Entomology, v.34, n.3, p.42933, 2005.

COSTA, S.M. et al. Chemical constituents from Lippia sidoides and cytotoxic activity. Journal of Natural Products, v.64, n.6, p.792-5, 2001.

DENT, D.R. Integrated pest management. London: Chapman \& Hall, 1995. 356p.

FIGUEIREDO, L.S. et al. Efeito da época de colheita na produção de biomassa e óleo essencial de alecrimpimenta (Lippia sidoides Cham.). Revista Brasileira de Plantas Medicinais, v.11, n.2, p.154-8, 2009.

GALLO, D. et al. Manual de entomologia agrícola. Piracicaba: FEALQ, 2002. 920p.

GIRÃO, V.C.C. et al. Efeito protetor do extrato etanólico de Lippia sidoides (alecrim-pimenta) nas gengivites marginais de cães. Ciência Animal, v.11, n.1, p.13-7, 2001.

LEITE G.L.D. et al. Role of canopy height in the resistance of Lycopersicon hirsutum f. glabratum to Tuta absoluta (Lep., Gelechiidae). Journal of Applied Entomology, v.123, n.8, p.459-63, 1999.
LEITE G.L.D. et al. Role of plant age in the resistance of Lycopersicon hirsutum f. glabratum to the tomato leafminer Tuta absoluta (Lepidoptera: Gelechiidae). Scientia Horticulturae, v.89, n.2, p.103-13, 2001.

LEITE G.L.D. et al. Níveis de adubação orgânica na produção de calêndula e artrópodes associados. Arquivos do Instituto Biológico, v.72, n.2, p.227-33, 2005.

LEITE G.L.D. et al. Fatores climáticos influenciam a abundância de artrópodes de plantas medicinais no Estado de Minas Gerais, Brasil. Revista Brasileira de Plantas Medicinais, v.8, n.3, p.43-51, 2006.

LORENZI, H.; MATOS, F.J.A. Plantas Medicinais no Brasil: nativas e exóticas. Nova Odessa: Instituto Plantarum, 2002. 512p.

MARSCHNER, $\mathrm{H}$. Mineral nutrition of higher plants. London: Academic Press, 1995. 889p.

MARTINS, E.R. et al. Plantas medicinais. Viçosa: UFV, 1994. 220p.

MELO, M.T.P. et al. Produção de fitomassa e teor de óleo essencial de folhas de alecrim-pimenta (Lippia sidoides Cham.) em diferentes espaçamentos de plantio. Revista Brasileira de Plantas Medicinais, v.13, n.2, p.234234, 2011.

SANTIAGO, G.P. et al. Effects of plant extracts on the biology of Spodoptera frugiperda (J. E. Smith, 1797) (Lepidoptera : Noctuidae) maintained under artificial diet. Ciência e Agrotecnologia, v.32, n.3, p.792-6, 2008.

SARTÓRIO, M.L. et al. Cultivo orgânico de plantas medicinais. Viçosa: Ed. Aprenda Fácil, 2000. 260p.

SILVA, F.W.S. et al. Nutrientes afetando as mudas de alecrim-pimenta (Lippia sidoides Cham.) e seus artrópodes. Revista Brasileira de Plantas Medicinais, v.11, n.1, p.18-23, 2009.

SIMÕES, C.M.O. et al. Farmacognosia: da planta ao medicamento. Porto Alegre: Ed. Universitária, 2000. $821 \mathrm{p}$.

SOUZA, M. F. et al. Calagem e adubação orgânica na produção de biomassa e óleo essencial em Lippia citriodora Kunth. Revista Brasileira de Plantas Medicinais, v.12, n.4, p.401-405, 2010.

TAIZ, L.; ZEIGER, E. Fisiologia vegetal. Porto Alegre: Artmed, 2004. 719p.

PRIMAVESI, A. Manejo ecológico de pragas e doenças: técnicas alternativas para a produção agropecuária e defesa do meio ambiente. São Paulo: Nobel, 1988. 137p.

VEHRS, S.L.C. et al. Comparison of population growth rate and within-plant distribution between Aphis gossypii and Myzus persicae (Homoptera, Aphididae) reared on potted chrysanthemums. Journal of Economic Entomology, v.85, n.3, p.799-807, 1992. 